\title{
Managerial Perspective on Open Source Collaboration and Networked Innovation
}

\author{
Katja Henttonen', Pasi Pussinen²,Timo Koivumäki ${ }^{3}$
}

\begin{abstract}
This study explores the managerial perspectives towards open source software and networked innovation. We analysed six software companies who use open source software as a significant part of their product or service offering. The study found notable differences in managerial attitudes, expected benefits and key challenges related to open source software and its role in innovative activities. While all companies were using same pieces of software with open source communities, there were different levels of engagement in the development of the software and information flows between companies and communities. A deeper level of involvement enables the exchange of more than just the code: like ideas, influences, opinions and even innovations or parts of them. The differences in managerial views on open source and networked innovation may be explained by industry domains, value chain position and leadership style
\end{abstract}

Keywords: open source; free software; external innovation; open innovation; technology management; digital commons.

'Service Development and Management, Digital Service Research. VTT Technical Research Centre of Finland. Kaitoväylä I, FI-9057I, Oulu, Finland. Email: katja.henttonen@vtt.fi.Phone: +358 40 821 7180.

${ }^{2}$ Value-Driven Service Business, Digital Service Research.VTT Technical Research Centre of Finland. Kaitoväylä I, FI-9057I, Oulu, Finland. Email: pasi.pussinen@vtt.fi.Phone:+358 40 35। 4858

${ }^{3}$ Digital Service Research.VTT Technical Research Centre of Finland. Kaitoväylä I, FI-9057I, Oulu, Finland.

Email: timo.koivumaki@vtt.fi. Phone: +358 40507363 I 


\section{Authors}

Katja Henttonen is a Specialist at Digital Services Research within the VTT Technical Research Centre of Finland. Her research interests are related to the delicate art of 'openness' in inter-organisational collaborations.

Pasi Pussinen is a Research Scientist in the Value-Driven Service Business Team at VTT Technical Research Centre of Finland. His research interests include open source software, business models and service dominant logic.

Timo Koivumäki is a Research Professor of Mobile Business Applications at the VTT Technical Research Centre of Finland and at the University of Oulu. His research interests include consumer behaviour in e-commerce, $\mathrm{m}$-commerce and ubi environments, user-driven innovation, mobile marketing, digital economy and information goods.

\section{Introduction}

Various business models based on free and open source software (FLOSS) have been widely studied in academia (e.g. Bonaccorsi et. al. 2004, Favaro and Pfleeger 201 I, Spiller and Wichmann 2002, Lerner and Tirole 2002). However, there seems to be relatively little research into why some open source companies take a very proactive role as FLOSS developers/advocates while others only use publicly available FLOSS resources and minimise any community involvement. This difference is not evident from FLOSS business-model literature because most known business models can be linked with either approach.

This study was born from a desire to understand key factors and determinants that turn companies into 'passive exploiters' or 'active contributors' in FLOSS. The focus is on analysing the difference in managerial perspectives towards open source and networked innovation. The selected research approach is a multiple case study of six software companies which all utilise FLOSS intensively but differ in terms of their engagement with FLOSS communities. Theory-wise, the study benefits from Chesbrough's $(2003,2006)$ open innovation paradigm and, more specifically, builds on the difference between 'external innovation' and 'open innovation' which was proposed by West and Gallagher (2004, 2006). This paper claims that companies who actively contribute to FLOSS development have adapted the open innovation paradigm, while mere exploiters employ the external innovation model. Following Valkokari et. al. (2009), we use the term 'networked innovation' to refer to all externally-orientated approaches to innovation, including both 'open innovation' and 'external innovation'.

The results suggests that FLOSS companies can indeed be meaningfully categorised into 'external innovators' and 'open innovators' and that there are significant differences between the two.The managers of the two kinds of companies view FLOSS differently, expect different operational benefits from it, face different challenges and, consequently, employ contradictory managerial techniques. For example, external innovators view FLOSS as a 'free lunch' and look solely for cost savings while, open innovations perceive FLOSS as a fundamental element of value creation and seek to become shapers of the technologies in question. Further, external innovators mostly attempt to 'work around' conflicts of interest with FLOSS communities, while open innovators seek to establish maximum synergy with them to reap the benefits of pooled R\&D.

The rest of the article is structured as follows. The second chapter summarises theoretical concepts underlying the study and explores how they compare to some models used in prior FLOSS literature. The third chapter describes the research approach and methods employed in this study, and also briefly introduces the case study companies. The fourth chapter presents the actual case study results and presents a brief summary of them. The fifth chapter discusses the limitations of the study and gives suggestions for further research. Conclusions close the paper.

\section{Theoretical background}

\section{I Three innovation models: closed, external and open}

Over the past decades, co-operation and networks have come to the fore in innovation research (see e.g. Tuomi 2002 or Chesbrough 2006 for a historical review). Relatively recent ideas on the collaborative nature of innovation include, for example, the concepts of extended enterprise (Dyear 2000), open innovation (Chesbrough 2003, 2006), user-driven innovation (von Hippel 2005) and creation nets (Hagel and Brown 20 I I).This article builds mostly on Chesbrough's $(2003,2006)$ idea's on open innovation. His theory describes the recent tendency of companies to 'open up' their innovation processes. The main claim is that not all good ideas need to be developed internally, and not all ideas should necessarily be further developed within a firm's boundaries (ibid; Koskela et. al. 20I I). Two important characteristics of the Open Innovation theory are that it gives considerable attention to the purposive outbound flows of intellectual property (IP) and underlines the need to motivate the creation of relevant knowledge outside the company (ibid).

Based on Chesbrough (2003, 2006), West and Gallagher (2006a, 2006b) acknowledge three innovation models: closed innovation, external innovation and open innovation. In the closed innovation model, internal research and development (R\&D) activities feed the company's production pipeline and 
products are brought to market by the company itself. In the external innovation model, the company seeks to develop what Cohen and Levithal (1989) termed 'absorptive capacity' and utilises external sources of innovation such as universities, customers, supplies and competitors. However, very much like in the closed innovation model, the outbound flows of intellectual property (IP) are viewed as unwitting 'spill-overs'. While sharing some characteristics with external innovation, the open innovation model goes beyond. Instead of merely exploiting what 'happens' to be available, open innovators employ a systematic strategy for motivating the creation of external knowledge. They also use purposive outward IP flows to reach new markets and maximise returns on internal innovation. Table I (on the next page) summarises the characteristics of each model, showing the managerial attitudes, key challenges and resulting managerial techniques associated with each. This paper focuses on the difference between external and open innovation. For clarity, the characteristics that distinguish open innovation from external innovation are underlined.

The difference between external and open innovation is in line with the recent study (Paasi et al 2010, Luoma et al 2010) on intellectual property management in inter-organisational networks. Based on their extensive empirical study (ibid) and the knowledge management theory of Grand and Baden-Fuller (2004), the authors recognised two cat- egories of inter-firm relationships: 'knowledge co-creation relationships for knowledge exploration' and 'knowledge transaction relationships for knowledge exploitation'. The former focuses on joint knowledge creation and resembles open innovation; the latter focuses on the efficient utilisation of existing knowledge and can be associated with the external innovation model. The stated difference between external and open innovation also contains clear analogies with other categorisations of innovation practices such as 'inboud open innovation vs. open value co-creation' by Koskela et. al. (20I I), 'user cluster vs. open cluster' by Indrissal et. al. (2012) and 'Explorers vs. Professionals' by Kaup and Gassman (2009).

The term 'open innovation' is sometimes used to describe all scenarios where companies create profits from open source software. However, increasingly many software-intensive companies appropriate assets from FLOSS communities and use them to create proprietary products, without making any noticeable contributions back (Dahlander and Magnuson 2005; Stams 2009). Lacking steps to motivate the in-flows of external IP or to benefit from outbound IP flows, such an approach exemplifies the external - rather than open - innovation model (West and Gallagher 2006). In contrast, the open innovation model entails some reciprocal interaction with FLOSS communities (ibid). Such reciprocity enables learning through co-creation (cf. Krogh et. al. 2003)

\begin{tabular}{|c|c|c|c|}
\hline $\begin{array}{l}\text { Innovation } \\
\text { model }\end{array}$ & Managerial attitudes & Key managerial challenges & Related managerial techniques \\
\hline $\begin{array}{l}\text { Closed } \\
\text { innovation }\end{array}$ & $\begin{array}{l}\text { Only internal R\&D } \\
\text { matters, 'not invented } \\
\text { here' syndrome } \\
\text { Fierce protection against } \\
\text { spill-overs }\end{array}$ & $\begin{array}{l}\text { 1. Attract the best talent into the } \\
\text { company } \\
\text { 2. Exploit own research } \\
\text { commercially }\end{array}$ & $\begin{array}{l}\text { 1. Provide excellent compensation, resources } \\
\text { and freedom to internal inventors } \\
\text { 2. Provide a dedicated development function } \\
\text { to link research with market knowledge }\end{array}$ \\
\hline $\begin{array}{l}\text { External } \\
\text { innovation }\end{array}$ & $\begin{array}{l}\text { Harvesting external } \\
\text { ideas, 'innovation } \\
\text { happens elsewhere' } \\
\text { Modest protection } \\
\text { against spill-overs }\end{array}$ & $\begin{array}{l}\text { 1. Explore a wide range of } \\
\text { sources for innovation } \\
\text { 2. Integrate external knowledge } \\
\text { with own innovative activities }\end{array}$ & $\begin{array}{l}\text { 1. Scan environment carefully } \\
\text { 2. Develop absorptive capacity, utilise } \\
\text { networks }\end{array}$ \\
\hline $\begin{array}{l}\text { Open } \\
\text { innovation }\end{array}$ & $\begin{array}{l}\text { Facilitating external } \\
\text { innovation, pooled } \\
\text { R\&D, 'innovation } \\
\text { happens together' }\end{array}$ & $\begin{array}{l}\text { 1. Motivate the creation } \\
\text { and contribution of external } \\
\text { knowledge } \\
\text { 2. Incorporate external } \\
\text { knowledge with own innovative } \\
\text { activities } \\
\text { 2. Maximise exploitation of } \\
\text { diverse IP resources }\end{array}$ & $\begin{array}{l}\text { 1. Provide intrinsic rewards for contributions } \\
\text { 2. As in external innovation } \\
\text { 3. Share or give away IP to maximise returns } \\
\text { from entire innovation portfolio }\end{array}$ \\
\hline
\end{tabular}

Table I.Three innovation models summarised, modified from West and Gallagher $(2004,2006)$

ISSN: 07I 8-2724. (http://www.jotmi.org)

Journal of Technology Management \& Innovation @ Universidad Alberto Hurtado, Facultad de Economía y Negocios. 
and ensures so that communal resources are continuously replenished (Dahlander and Magnuson 2005). As open innovation companies have internalised the idea that willing spill-overs can be beneficial, they are not 'scared' of releasing their own IP to the FLOSS domain in order to achieve promotional or strategic goals (cf. Henkel 2006).

West and Gallagher (2006a; 2006b) name two main challenges for external innovation and three for open innovation. The first challenges for external innovators is exploring the wide range of knowledge sources, i.e. to perform environmental scanning to find out what happens on the FLOSS scene and what could be exploited from there. Meanwhile, open innovators define their challenge in terms of motivating external innovation i.e. how to keep open source continuously producing inputs that are beneficial for the company. The second challenge of integrating external and internal activities is shared by both external and open innovators and contains a diverse set of diverse legal, technical and business issues. The third challenge is only accepted by open innovators and it relates to the maximisation of returns by giving away 'surplus' intellectual property.

\subsection{Other 'categorisations' of commercial FLOSS engagement}

There are some prior studies which have aimed to categorise FLOSS companies according to the 'intensity' of their engagement with FLOSS communities. For example, Dahl- ander and Magnuson (2005) detected that companies adopt either a 'commensalistic', 'symbiotic' or 'parasitic' relationship with FLOSS communities (see also Lundell et. al. 2006). The symbiotic relationship resembles the open innovation model as both carry the idea of reciprocity and mutual benefit. Our study shows that what were herein describe as the 'external innovation model' can become a commensalistic relationship at best (this means benefiting from another entity while leaving it without harm) or turn into parasitic one at its worst.

Grand et. al. (2004) and Dahlander (2007) propose four modes of company involvement in FLOSS. Grand et al. (2004) understands their four levels as 'progressive': each level implies bigger investments and a greater reliance on FLOSS, but also more operational benefits and improved opportunities for knowledge sharing and learning. As presented in Figure I, the 'lowest' level of involvement could be associated with external innovation and the two 'upper' levels with open innovation as defined herein. In turn, Dahlander (2007) presents commercial FLOSS participation as a $2 \times 2$ matrix where the variables are the intensity of FLOSS participation (low/high) and the initiator of the project (the company itself or a wider community). This study is located on the other side of the matrix, focusing mostly on how companies engage in FLOSS projects initiated by others.

Thus, the proposed distinction between 'external innovators' and 'open innovators' is not at odds with classifications

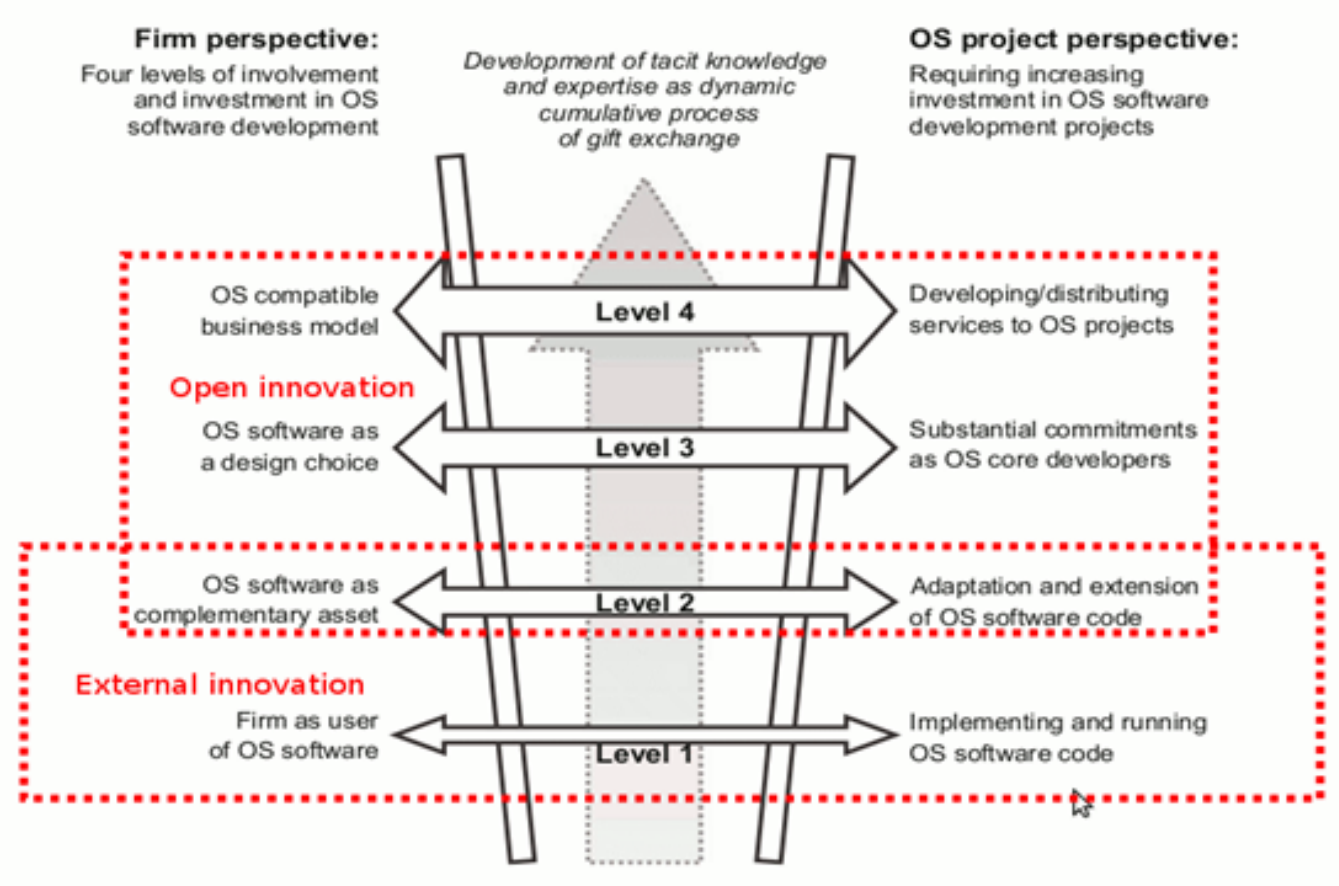

Figure I. Levels of FOSS involvement (from Grand et. al. 2004, red text/symbols added)

ISSN: 07I 8-2724. (http://www.jotmi.org)

Journal of Technology Management \& Innovation (c) Universidad Alberto Hurtado, Facultad de Economía y Negocios. 
in prior FLOSS literature. However, to our knowledge, this is the first article which studies the difference from the view point of innovation management.

\section{Methodology}

\section{I Research approach and case selection}

As stated previously, six small-scale case studies of open source companies were performed. Herein, multiple case studies were not used for the purpose of literal or theoretical replication; there was not yet a well-formed theory to 'test'. Instead, considering the preliminary and exploratory state of the research, the goal was to maximise the 'richness' of information for qualitative analysis (cf. Flyvbjerg 2006). Consequently, we selected case study companies which differ from each other in several dimensions, e.g. geographic location, size and software sector. All case study companies were required to comply with the following selection criteria: (a) utilise FLOSS intensively as part of their product or service offerings and b) have different levels of activity within FLOSS communities and thus be placed differently on the 'continuum' from external to open innovation. The case selection was also influenced by the ease of access: in five out of six cases, the interviewing authors and company personnel had already collaborated on other research projects. These prior collaborations gave us in-depth understanding on the managerial philosophy and practices of the case study companies and actually pointed to the research problem at hand (see Henttonen 20I I).

\subsection{Data collection and analysis methods}

The primary method of data collection was semi-structured interviews of company personnel. All interviews were literally transcribed. Other sources of evidence were online documentation and unobtrusive observation of employee interaction on FLOSS forums. These had a secondary role and were mainly used to collaborate and augment evidence collected in the interviews. In some cases, company partners were also contacted to confirm particular details. Qualitative method called Template Analysis was employed to thematically analyse the interview transcripts and, to a much smaller extent, some documentary evidence. In short, this means that a coding template was developed iteratively while the analytical process moved forwards. A short, initial version of the template reflected the pre-assumptions based on the theoretical frame while later versions were updated to reflect themes emerging from the data set. The final template served as a basis for interpreting the data and writing up the findings.

\section{Case study results}

This chapter presents the case study results. The first chapter analyses the managerial attitudes, challenges and techniques associated with the external innovation model. This model, in our view, is represented by companies F, C and A and, to a lesser extent, E.The second chapter discusses how the same managerial issues are faced by open innovators, i.e. companies D and B. Figure 2 presents how the companies are positioned on the continuum from external to open innovation.

\begin{tabular}{|l|l|l|l|}
\hline 'Alias' & Product offering & Size & Strategically important FLOSS products \\
\hline Firm A & $\begin{array}{l}\text { Embedded systems (hardware } \\
\text { and software) for automotive } \\
\text { and wireless industries }\end{array}$ & $\begin{array}{l}\text { Personnel 1000-2000 } \\
\text { turnover 100-200 } \\
\text { M€ }\end{array}$ & $\begin{array}{l}\text { Linux-kernel for most products lines, diverse FLOSS } \\
\text { applications (games, multimedia, office etc.) for } \\
\text { terminal end-user devices }\end{array}$ \\
\hline Firm B & $\begin{array}{l}\text { Customised business software } \\
\text { solutions and consultation } \\
\text { services for end-clients }\end{array}$ & $\begin{array}{l}\text { Personnel 50-100, } \\
\text { turnover below 2 M€ } €\end{array}$ & $\begin{array}{l}\text { Linux desktop solutions (Ubuntu), FLOSS databases } \\
\text { (MySQL, PostgreSQL), content management systems } \\
\text { (e.g. Plone, Joomla) and development tools (e.g. Zope) }\end{array}$ \\
\hline Firm C & $\begin{array}{l}\text { Embedded systems (hardware } \\
\text { and software) design as a } \\
\text { subcontractor }\end{array}$ & $\begin{array}{l}\text { Personnel 100-500, } \\
\text { turnover 10-30 M€ }\end{array}$ & $\begin{array}{l}\text { Embedded Linux-distributions, development tools } \\
\text { (e.g. Subversion, Bugzilla) }\end{array}$ \\
\hline Firm D & $\begin{array}{l}\text { Advanced web solutions for } \\
\text { both IT contractors and direct } \\
\text { end-clients }\end{array}$ & $\begin{array}{l}\text { Personnel 20-50, } \\
\text { turnover below 2 M€ } €\end{array}$ & $\begin{array}{l}\text { FLOSS databases (MySQL), content management } \\
\text { systems (e.g. Joomla, Drupal), e-commerce solutions } \\
\text { (Magento) and development tools (e.g. Zend } \\
\text { framework) }\end{array}$ \\
\hline Firm E & $\begin{array}{l}\text { Mobile software, media portals, } \\
\text { web-based enterprise software }\end{array}$ & $\begin{array}{l}\text { Personnel 1000- } \\
2000, \text { turnover 50- } \\
100 \text { M€ }\end{array}$ & $\begin{array}{l}\text { Mobile Linux (e.g. Android, Meego), content } \\
\text { management systems (e.g. Alfresco), enterprise } \\
\text { software platforms (e.g. Liferay) }\end{array}$ \\
\hline Firm F & $\begin{array}{l}\text { Embedded software for the } \\
\text { mobile/cellular industry }\end{array}$ & $\begin{array}{l}\text { Personnel below 20, } \\
\text { turnover below 1 M } €\end{array}$ & $\begin{array}{l}\text { Embedded Linux distributions, user interface } \\
\text { development tools (e.g. GTK) }\end{array}$ \\
\hline
\end{tabular}

Table 2. Summary of the case study companies

ISSN: 07 I8-2724. (http://www.jotmi.org)

Journal of Technology Management \& Innovation (C) Universidad Alberto Hurtado, Facultad de Economía y Negocios. 
External innovation

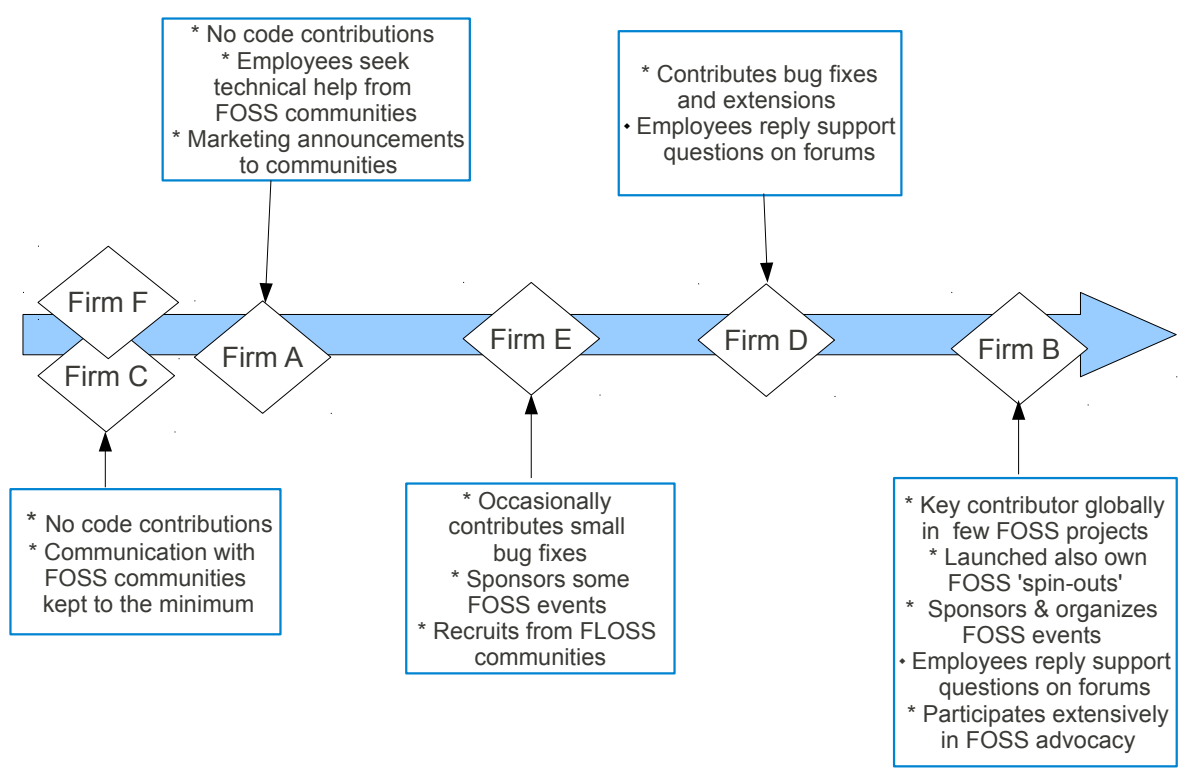

Figure 2. Six case study companies placed on the continuum from external to open innovation

\section{I FLOSS as external innovation}

\section{I.I Managerial attitudes and goals}

External innovators did not perceive FLOSS communities as part of their value network - instead, publicly available source code was seen more like a 'bulk' resource on which to feed.They all saw free-of-charge software artefacts as the main 'gain' from FLOSS, underlining how cost and time savings had helped them to offer reduced prices, make bigger profit margins and/or achieve shorter lead times to market. They also recognised that the cost advantage was far from being marginal: a couple of companies said that they could never have entered a particular market without FLOSS. 'There were initially very few [mobile] terminal vendors who could afford building platforms based on proprietary systems... but now we have an [open source] software pool that has helped to kick-start many new vendors [like us],' explains a manager from company $E$.

Considering the heterogeneity of the case study companies, it is hardly surprising that FLOSS has a different place in their innovation processes. For a couple of companies, FLOSS was a free-of-charge 'base brick' on which their own products were built. For example, a manager from company E explains, 'Open source is not value adding: it is simply a matter of getting the base software stack in a very mature state from day one and then you can concentrate on adding your true value.' Others viewed FLOSS more like a decorative chimney stack, bringing something extra on top of their own products: 'We keep receiving free-of-charge updates ... we can just say to the customer that "Hey, our next release contains this fascinating new feature" ...we hardly have to think about new features by ourselves.' However, what was common to all companies classified by us as 'external innovators' was their tendency to view FLOSS as a 'free lunch'. Despite gaining significant business benefits from FLOSS, the companies felt unwilling to contribute anything. Their answers reflected attitudes which are characteristics to closed and external innovation models. Mostly, FLOSS contributions were perceived as giving money to a charity: a benevolent, but eventually wasteful, activity that a company could not afford in the long run (with the possible exception of small PR investments). One interviewee from company $E$ restructured the question in terms of 'Why would anybody contribute?'. He continued: 'You are not giving gold for free to anybody. It is like a joke that, you know, "Oh its open sourced, everybody contributes"... hah, nobody contributes, especially not the big companies focusing on assets protection'. FLOSS participation was also likened to a 'janitor's job' something that is undoubtedly necessary but not attractive technically or monetarily - so let somebody else do it. Further, some said that their customers were quasi-paranoid about openness: 'If we started hanging out on open source forums, they [customers] may think that we will tell their secrets to the world... even if we did not, it would cast a shadow of doubt.'

ISSN: 07 I8-2724. (http://www.jotmi.org) 
Despite the underling cost and time savings, two external innovators also tried to exploit other opportunities within FLOSS to a limited extent. For example, company A sends marketing announcements to the mailing lists of FLOSS communities when a new product comes out. Company $\mathrm{E}$ has gone a step further and builds its brand by contributing small bug fixes and sometimes even sponsoring FLOSS events. Their principal software architect explains how the company occasionally manages to get 'fifteen minutes of fame' with minimal contributions and concludes: '[FLOSS] communities are important for marketing, and not just marketing towards customers but also marketing towards developers, enabling the company to hire smart brains... no doubt about that.'

\subsubsection{Managerial challenges}

The first challenge mentioned for external innovators relates to exploration. Interestingly, several interviewees mentioned that it was very difficult to keep up-to-date on what is happening on the FLOSS scene. This was blamed on insufficient human resources internally or the need to keep all resources engaged in customer projects, leaving an impression that environmental scanning was seen secondary, after all. However, a senior specialist from company A expressed that his top-management should definitely pay more attention to the issue:

'We are pretty unorganised on this [scanning for FLOSSrelated innovation]... it is useless to go randomly surfing the Internet every Tuesday morning like "la di da, can't find anything here, let's try again next week" - instead, we should really have a carefully managed process for staying up-to-date on the latest FLOSS developments.'

The second challenge is to 'integrate external knowledge with own innovative activities'. On this area, the key issues for the interviewed companies related to quality assurance, legal liabilities and release maintenance. The quality-related challenges were very much in line with what has already been widely reported. It was underlined that FLOSS never provides any guarantees on quality and therefore each component has to go through an internal quality assurance and testing pipeline.

GPL i.e. GNU General Public Licence is one of the most wellknown and widely used FLOSS licenses. It is based the idea of 'copyleft' and is particularly strict in its requirements for developers to release the source code of derived or joint work (see e.g. McGowan 2005).

Such tools analyze software packages from a legal perspective, searching source code for license declarations and technical interdependences which impact how licensing terms propagate (for more information see e.g. Oksanen 2006)
As to legal challenges, it was said to require significant skills to 'make sense' of a multitude of FLOSS licences, e.g. regarding reciprocal compatibility and propagation mechanisms (cf. Dahlander 2005; Henttonen and Matinlassi 2008). Further, many customers were reportedly unwilling to accept the reciprocity demands of FLOSS licences, especially those made by the popular GPL licence. One interviewee (company $A$ ) noted that such resistance is often based on a fixed world view rather than careful business analysis:'Even when it's a totally irrelevant component, no business secrets, no patents, no major expertise, nothing... they oppose [open sourcing it] merely out of principle... they just cannot imagine another way.'

The most prominent challenges related to release maintenance. Since the companies do not contribute their own modifications to FLOSS communities, they have to maintain a separate version of the product, a kind of in-house 'fork' (cf. Nyman and Mikkonen 20II) by themselves. Thus, major effort is required to synchronise their own FLOSS-based product with the community version. If an original FLOSS community splits apart, creating more 'forks', the company has to merge its own product with several versions. This is closely intertwined with the questions of control and power. The company may be very negatively affected by a community's decisions: on technology standards, product architecture and release cycles. But, as the company is 'nobody' inside the FLOSS community, there is little use to raise objections:

'This [influencing a FLOSS community] is tricky diplomacy... you cannot create a forum account on one day and go there on next day to tell people what to do. You are first required to build respect and a [brand] name for yourself by being committed and contributing. This applies to individuals and companies alike... Despite being a big company and enjoying an established position in the industry, we are absolutely nobody in the FLOSS world.'

(Senior specialist, company A)

\section{I.3 Managerial techniques}

Since the companies devote little or no effort in environmental scanning, how do they find out about new FLOSS projects with business relevance? The companies depend heavily on individual employees who are 'hobbyists' and contributors in FLOSS projects in their free-time. For example, when asked how they kept an eye on new developments with mobile Linux, the representative of company $F$ replied openly: 'We cannot afford to use working time [on this].... but Linux is a hobby for the most [of the employees] so we will stay up-to-date that way.' Sometimes companies can maintain a dialogue with key FLOSS communities through individual employees who reportedly make significant contributions in their free-time and thus have a 'name' in those

ISSN: 07 I8-2724. (http://www.jotmi.org)

Journal of Technology Management \& Innovation @ Universidad Alberto Hurtado, Facultad de Economía y Negocios. 
communities. However, despite their reliance on employees' own FLOSS enthusiasm, the companies do not give any specific rewards for this. So, somewhat surprisingly, external innovators seemed to depend, not only on the volunteer contributions from external FLOSS developers, but also on those from their own employees. Because these companies had indicated strong worries about 'unwitting' spill-overs, it was interesting that they preferred their employees to be involved in FLOSS communities as individuals, or 'hobbyists', instead of a more-controlled policy.

There were relatively well-defined managerial techniques in place to address challenges regarding legal liabilities and quality assurance. The companies use a combination of dynamic and static testing, very much like those described by some previous authors (e.g. Maki-Aisala and Matinlassi 2006). As to legal issues, two companies use automatic licensing tools and most add empty 'glue code' in order to isolate FLOSS code from their own or customer's code. The 'glue code' layers are often totally void of functionality and do nothing to aid component interoperability. Instead, their sole purpose was to stop GPL licensing terms from propagating and thereby avoid associated liabilities (e.g. reciprocity demands, patent licensing etc.) The practice was perceived to be a 'rule' rather than an exception in FLOSS business:

'The common line with these [mobile software] products is that what is open sourced are the trivial parts, because the real costly things, that is IPR... is never open sourced... one can do that with the GPL as well, because big companies are just using open source empty glue layers and then, you know, protecting their assets.'

\section{(Principal software architect, company E)}

Interestingly, even though interviewees emphasised challenges related to release maintenance, they could not name any concrete steps taken to address them. It seems that most took for granted that FLOSS projects are unpredictable/uncontrollable by 'nature' and this was just 'a risk to live with'. However, as a side note - the companies did share some of the same software development tools with communities, like GIT and Bugzilla.

\subsection{FLOSS as open innovation}

\subsection{Managerial attitudes and goals}

Open innovators had clearly different rationales for their FLOSS involvement. FLOSS communities were understood as an important part of the external value network and were deemed essential for global marketing, inter-organisational learning and joint development. Both companies B and D found most of their customers either through general vis- ibility on FLOSS forums or through direct references from other community members. 'It is here [in the OSS world] where we get complete visibility, says the marketing director of company B, explaining that they had practically abandoned conventional marketing in favour of FLOSS networking (cf. Henttonen 20I I).

The importance of inter-organisational learning was also underlined; company $B$ had integrated employee training with the participative learning methods of FLOSS communities. In addition to technical learning, the communities were a source of information on what is happening in the market. The CEO of company D explains that the FLOSS world is full of excellent online conferences, blog sites and other resources which help him to stay informed on, 'What is hot and what is up right now on the market,' adding that such market knowledge obtained from FLOSS forums, has greatly assisted him in positioning his company favourably.

The cost and time savings related to FLOSS were equally important to 'open innovators' - however, these were viewed as a successes of joined development or 'pooled R\&D' rather than as a 'free lunch'. The importance of reciprocity was underlined in several accounts. For example, the CEO of company $B$ explains that his company could have never built mature software from 'scratch' and continues, "I could never achieve anything like that without open source and, well, when I benefit from the efforts of others I cannot expect to keep all profits to myself.' (cf. Henttonen 20I I). He continues to underline the importance of contributing to the FLOSS projects on which his company depends:

'If you are part of the ecosystem you have do things to sustain that ecosystem. If you are just a consumer, then that ecosystem will sooner or later die... in order to make the open source ecosystem stable, you [a company] have to start looking at other aspects than just being a consumer... to contribute in different ways and make sure that the ecosystem stays alive.' (General Executive Officer, company A) FLOSS participation was also seen as an opportunity become 'shapers' rather than just 'users' of a particular technology. The difference was also noticed by customers. 'They [customers] come to us because they see us as people who envision the [FLOSS] product and not only as people having [third-party] expertise on it,' says the marketing director of company A.

The interviewees either did not know or did not openly admit it, but the described 'glue code' models are known to be 'grey' or borderline cases legally (e.g. Hopner 2004 ). They are clearly not 'safe' but reduce risks compared to boldly ignoring the GPL terms. 
Further, both companies D and B had internalised the open innovation 'philosophy' that one should never 'sit' on surplus IP. For example, whenever they have a piece of source code, which has reached the end of its life cycle, they put it freely available on SourceForge or another similar FLOSS platform. Sometimes there are surprising benefits when the IP gets 'a new life' in the FLOSS domain. For example, company $B$ open sourced a very small business software, which was only meant to be used in-house (Henttonen 20II). Later, they were contacted by a big foundation, which had found the software from the Internet and wanted to have it extended. Thus, they got a very important customer with minimal 'marketing' effort

\subsubsection{Managerial challenges}

It seems that while external innovators struggle to stay tuned to developments on the FLOSS scene, open innovators use FLOSS forums to keep up-date-on on what is "hot and in', not only on FLOSS, but on the software markets in general.To address the challenge of motivation, open innovators make significant contributions to FLOSS communities, e.g. by committing resources to open software development and by co-organising FLOSS events. This raised an obvious question on how they can afford so many activities which do not generate revenues directly.

From the integration challenges mentioned previously, only quality assurance concerns were mentioned by open innovators. In stark contrast with external innovators, licence compatibility issues and other legal 'risks' were seen as fundamentally non-threatening due to close and friendly ties with legal copyright owners, i.e. the communities. The afore-mentioned problems on release maintenance were also eliminated: since base software was developed together with the community, there was no need to maintain a separate version for 'them' and 'us'. For open innovators, the biggest integration challenges related to developing the technical, social and business skills required by 'fully fledged' FLOSS involvement. Because such skills are not commonly taught in universities, they have to make significant investments in teaching the 'FLOSS ways' to new employees.

As to willing spill-outs and spin-offs, the biggest challenge named by open innovators were so called 'open source piracy'. This means that sometimes competing software companies appropriate the source code but illegally ignore the reciprocity terms of the FLOSS licence. This often means that potential benefits and 'credit' of the released IP goes to a competitor and nothing comes back to the original owner of the IP. This type of piracy was said to be common and it is exactly what some 'external innovators' in this study admitted to.

\subsubsection{Managerial techniques}

When asked about the affordability of non-direct investments, open innovators replied that whole-hearted FLOSS participation requires 'energy and passion' rather than big monetary investments. To exemplify such an attitude, their marketing director run a city marathon dressed as a blue elephant, a mascot of a well-known open source project, Postgre SQL.This earned the company five minutes of fame on a national TV channel. Once the CEO had contacted a local refugee centre and asked them to translate OpenOffice into an 'exotic' language. So, despite being a mediumsized company, they showed something that could be called 'community spirit'. While external innovators relied on the FLOSS enthusiasm of individual employees, the managers of open innovation companies were clearly the sources of such enthusiasm themselves.

Open innovators shared quality assurance concerns with external innovators, but adopted totally different techniques to address this challenge. First, they picked-up FLOSS software with a 'good reputation', they used their excellent social networks to accumulate knowledge on quality issues and made decisions on that basis. Secondly, they engaged some of their customers in the co-development and co-testing of products. The technical manager of company B says, 'The only way to test a product is to test with a customer and slowly start working to stabilise it... when I give software to them [certain customers] at a low cost, I can do some beta-testing, some R\&D on them... this is how we bring in stable code.'

This was seen as an important continuum from FLOSS development practices which has always emphasised end-user involvement in R\&D. This is just one example of the "ways of doing things' adopted from FLOSS communities. Another example comes up when looking at how they respond to the aforementioned challenge of training new employees. In both companies $B$ and $D$, employee training follows the classic 'onion model' (Ye at Kishida 2003) which is frequently used to describe how participative learning occurs in FLOSS communities. New employees started by following discussions on FLOSS forums and were encouraged to gradually deepen their participation and eventually make contributions of their own.Within FLOSS communities, new employees are 'coached' by external experts free-of-charge which supports in-house training efforts.

To fight against unwanted appropriation by competitors, the companies always used a GPL licence when giving out their own intellectual property. Interestingly, a licence that was mentioned as a management challenge for external innovators, was a protection technique for open innovators. While GPL licensing terms can also be circumvented (as shown in

ISSN: 07I 8-2724. (http://www.jotmi.org)

Journal of Technology Management \& Innovation (C) Universidad Alberto Hurtado, Facultad de Economía y Negocios. 
section 4.1.3), the companies saw it as a relatively efficient tool against unwanted appropriation (justifiably, see Hopner 2004).

\subsection{Summary of the results}

This study has explored managerial views on open source and networked innovation in six case study companies. The results are summarised in Table 3.The study showed that there are fundamental differences in the managerial attitudes: while the management of external innovators clearly present an exploitation attitude and see FLOSS as a 'free ride 'to cost savings, the managers of companies with an open innovation approach see FLOSS as a fundamental element of their value creation process. Furthermore, open innovators clearly see FLOSS as a 'two-way street' of giving and receiving. There are also notable differences in the way the managers see the main challenges and in the way these challenges are tackled. For example, external innovators see the reciprocity demands of FLOSS licences, especially GPL, as a major obstacle and actively seek ways to work around it. Open innovators have a totally opposite view on the issue: they view open source piracy as a major challenge and see strong licensing schemes such as GPL, as a valid protection technique.

\section{Discussion}

There are problems in the methodological design of the study. With hindsight, the case study companies did not have enough common denominators: while the heterogeneity of companies may indeed have contributed to a diversity of viewpoints, it also diminishes the value of analytical comparisons between the companies. Further, one of the key advantages of the case study approach is that 'rich' contextual information on the studied organisations can be provided (Chetty 1999; Bryman 2008). However, in this study, such information is confined to few company characteristics presented in a table form; a more elaborate description of the companies could have improved the value of the findings and helped others to assess their transferability to other settings (Bryman 2008; Flyvbjer 2006). Then, of course, there are the known limitations of the case study approach in general: even when multiple case studies are performed, the results cannot be generalised as such. With hindsight, qualitative interviews with a few dozen carefully selected companies could have better served our purpose than a multiple study design. On the other hand, intensive collaboration with a few organisations allowed us to build better 'rapport' with the interviewees and make them openly discuss sensitive issues such as legally 'shady' attempts to circumvent licensing terms. Further, we also find it interesting that certain clear regularities/similarities in management perspectives emerged despite the heterogeneity of the cases, suggesting that the proposed concepts do have some broader relevance.

Looking at the case study companies, we see that the companies with the most 'exploitative' relationship with FLOSS are embedded systems providers and positioned as subcontractors in the value chain. On the other hand, the companies which are most deeply involved in open innovation

\begin{tabular}{|c|c|c|c|c|}
\hline \multirow{3}{*}{$\begin{array}{l}\text { Pattern of } \\
\text { involvement } \\
\text { External } \\
\text { innovation }\end{array}$} & \multirow[b]{2}{*}{$\begin{array}{l}\text { Managerial } \\
\text { attitudes }\end{array}$} & \multicolumn{2}{|c|}{ Managerial perspective } & \multirow[b]{2}{*}{$\begin{array}{l}\text { Challenge management } \\
\text { techniques }\end{array}$} \\
\hline & & Main Benefit & Main challenges & \\
\hline & $\begin{array}{l}\text { Exploitation } \\
\text { attitude: } \\
\text {-FLOSS is a bulk } \\
\text { resource } \\
\text { - FLOSS is a 'free } \\
\text { lunch' }\end{array}$ & $\begin{array}{l}\text { - Savings in } \\
\text { development } \\
\text { costs and time } \\
\text { - Efficient } \\
\text { resource } \\
\text { utilisation }\end{array}$ & $\begin{array}{l}\text { - FLOSS-related } \\
\text { knowledge acquisition } \\
\text { - Quality assurance } \\
\text { - FLOSS licensing } \\
\text { - Release maintenance }\end{array}$ & $\begin{array}{l}\text { - Passive management } \\
\text { (dependence on individual } \\
\text { employees) } \\
\text { - Dynamic and static testing } \\
\text { - Use of automatic licensing tools } \\
\text { and empty glue code }\end{array}$ \\
\hline $\begin{array}{l}\text { Open } \\
\text { innovation }\end{array}$ & $\begin{array}{l}\text { Contribution } \\
\text { attitude: } \\
\text { - FLOSS as an } \\
\text { integral element of } \\
\text { value (co-)creation } \\
\text { - FLOSS seen as } \\
\text { an effective way to } \\
\text { shape technology }\end{array}$ & $\begin{array}{l}\text { - Value co- } \\
\text { creation with } \\
\text { communities } \\
\text { - Inter- } \\
\text { organisational } \\
\text { learning } \\
\text { - Global } \\
\text { networks for } \\
\text { marketing }\end{array}$ & $\begin{array}{l}\text { - Quality assurance } \\
\text { - Maintaining the } \\
\text { FLOSS talent pool } \\
\text { - Open source piracy }\end{array}$ & $\begin{array}{l}\text { - Utilisation of social networks to } \\
\text { gain quality-related knowledge } \\
\text { - Co-development and co-testing } \\
\text { with customers } \\
\text { - Adopting peripheral FLOSS } \\
\text { participation as part of employee } \\
\text { training } \\
\text { - Strong FLOSS licensing schemes, } \\
\text { particularly GPL }\end{array}$ \\
\hline
\end{tabular}

Table 3. Summary of the case study results

ISSN: 07 I8-2724. (http://www.jotmi.org)

Journal of Technology Management \& Innovation (c) Universidad Alberto Hurtado, Facultad de Economía y Negocios. 
are software service providers with direct contact to end clients. For embedded systems providers, software forms a cost rather than a profit centre (cf.West 2007) and, thus, it might not be surprising that these companies stated cost savings as the biggest drivers for using open source software. Thus, even though 'widget frosting' can be considered as one of the most pivotal open source business models (e.g. Hecker 1999, Henkel 2006), in our study it not did seem to embrace innovations from community or interaction with the communities. For those companies who acted as subcontractors, contributing was also constrained by the fear of (customer's) sensitive information leaking out. In turn, the bespoke software companies that seemed more dependent on FLOSS communities as their main value proposition are focused around open source software. The core competence of these companies - services - is enhanced by the outside effects of open source and open innovation and there might be less threat of sensitive data or know-how leaking outside. It is obviously impossible to make conclusions in this regard based on six case studies, because the above relationships are probably incidental. However, the study suggest that differences in the value chain position and the related networked business models may create restrictions in the ways that open source can be applied. Beyond the software industry, prior studies (e.g. Savitskaya et. al. 2010) have found correlations between the value chain position and the 'openness' of innovation practices. It seems that more research is required to explore how the value chain position influences the companies' motivation and ability to contribute to FLOSS. One could also have deeper look at well-known open source business models to see whether they encourage a 'mindset' of exploitation or contribution. Because sustaining the pool of contributors is necessary for the long-term survival of the FLOSS phenomenon (cf. Hippel 2003, Dahlander and Magnuson 2005), the question is hardly trivial.

Alternatively, the difference between 'external innovators' and open innovators' could also be explained in terms of leadership (cf. Sanchez et. al. 20I I): the former seem to apply passive, and the latter, an active management approach towards FLOSS. For example, external innovators acknowledge the 'uncontrollability' of FLOSS as a given business risk while open innovators participate in FLOSS communities for the very reason of being able to control. For another example, external innovators passively rely on the enthusiasm of individual employees as FLOSS 'hobbyists', while top managers in open innovation companies are inputting their own 'energy and passion' in order to catalyse active FLOSS participation. The relationship between leadership style and FLOSS involvement might also be an interesting subject for further enquiry.

\section{Conclusions}

The study investigated the management perspective towards open source collaboration and networked innovation in six software companies. From our empirical data, two opposite managerial views on community collaboration arose. The first view sees community participation as a cost or an unnecessary burden by the management. The open source community is seen as a resource pool of some kind, only in terms of a free-of-charge software artefact, and company interaction with the communities is limited to minimal. The second view is a complete opposite one, in this view collaboration with open source communities is seen as an investment. As a return of their investment, these companies expect opportunities for global marketing and inter-organisational learning as well as cost savings through pooled R\&D. The latter view is compatible with the open innovation paradigm, while the former could be better described as 'external innovation'. The difference between the two managerial views could be explained in terms of industrial domain, value chain position, leadership style or even open source business models. More research is required to understand what causes a company to adopt either managerial perspective on FLOSS.

\section{References}

BADEN-FULLER, C. (2004). A Knowledge Accessing Theory of Strategic Alliances. Journal of Management Studies, 4I (I), 1467-6486.

BONACCORSI, A. Rossi, C. Giannangeli, S. (2004). Adaptive Entry Strategies under Dominant Standards - Hybrid Business Models in the Open Source Software Industry. SSRN Electronic Journal, I-23.

BRYMAN A. (2008). Social Research Methods. Third Edition. Oxford University Press, New York.

CHESBROUGH H. (2003). Open innovation: the new imperative for creating and profiting from technology. Harvard University Press, Boston.

CHESBROUGH, H (2006). Open Business Models: How to Thrive in the New Innovation Landscape. Harvard University Press, Boston.

CHETTY, S. (1996). The case study method for research in small and medium sized firms. International Small Business Journal I5(I), 73-85.

COHENW. Levinthal, D. (1989). Innovation and learning: the two faces of R\&D. The Economic Journal, 99(397), 569-596.

ISSN: 07 I8-2724. (http://www.jotmi.org)

Journal of Technology Management \& Innovation (c) Universidad Alberto Hurtado, Facultad de Economía y Negocios. 
DAHLANDER, L. (2005). Appropriation and appropriable in open source software. International Journal of Innovation Management, 9(3), 259-285.

DAHLANDER, L. (2007). Penguin in a new suit: a tale of how de novo entrants emerged to harness free and open source software communities. Industrial and Corporate Change, 16(5), $913-943$.

DAHLANDER, L. Magnusson M. (2005). Relationships between open source software companies and communities: Observations from Nordic firms. Research Policy, 34(4), 48I-493.

DYER, J (2000). Collaborative Advantage: Winning Through Extended Enterprise. Oxford University Press, New York.

FAVARO, J. Pfleeger, S. (20I I). Software as a Business. IEEE Software, 28(4), 22-25.

FLYVBERG, B. (2006). Five Misunderstandings About CaseStudy Research. Qualitative Inquiry, I2(2), Pp-245.

GRAND, S. Von Krogh, G. Leonard, D. Swap, W. (2004) Resource allocation beyond firm boundaries: $A$ multi-level model for Open Source innovation. Long Range Planning, $37(6), 591-610$.

HAGEL, J. Brown J. (20I I) Creation nets: harnessing the potential of open innovation. Journal of Service Science, I(2), 27-40.

HECKER, F. (2009). Setting Up Shop :The Business of OpenSource Software. IEEE Software, I6(I), 45-5I.

HENKEL, J. (2006). Selective revealing in open innovation processes: The case of embedded Linux. Research Policy, 35(7), 953-969.

HOPNER, J. (2004). The GPL prevails:An analysis of the firstever Court decision on the validity and effective of the GPL. SCRIPT-ed, I (4), 628-635.

HENTTONEN, K. Matinlassi, M. (2007). Contributing to Eclipse - a case study. Proceedings of the Software Engineering 2007 Conference (SE2007). Hamburg, Germany, 27-30 March, 2007.

HENTTONEN, K. (20I I). Libre Software as an Innovation Enabler in India: Experiences of a Bangalorian Software SME . In: Hissam S. Russo B. (Eds.), Open Source Systems: Grounding Research. IFIPAdvances in Information and Communication Technology,Volume 365, Springer, Boston. pp. 220-232. HIPPEL, E (2003). Open source software and the private- collective innovation model: Issues for organization science. Organization science, 209-223.

HIPPEL, E (2005). Democratizing Innovation. Cambridge, MA: MIT Press.

IDRISSIA, M.Amaraa, N. Landrya, R. (2012) SMEs' Degree of Openness: The Case of Manufacturing Industries. Journal of Technology Management and Innovation, 7(I), I86-210.

KEUPP, M. Gassmann, O. (2009). Determinants and archetype users of open innovation. R\&D Management, 39(4), 33 I-34I.

KING, N. (1998) Template analysis. In: Symon G. Cassell C. (Eds.), Qualitative Methods and Analysis in Organizational Research:A Practical Guide. Sage Publications, California. Pp. II8-I34.

KOSKELA K. Koivumäki T. Näkki P. (20I I) Art of opennesses. In: Pikkarainen M. Codenie W. Boucart N. Heredia J. (Eds.), The Art of Software Innovation, Springer, Berlin. pp. 57-68.

KROGH G., Spaeth S. Lakhani K. (2003) Community, joining, and specialization in open source software innovation: a case study. Research Policy, 32 (7), Pp. |2|7-124|

LERNER, J.Tirole,J. (2002). Some Simple Economics of Open Source. Journal of Industrial Economics, 50(2), 197-234.

LUNDEL, B. Ling, B. Lindqvist, E. (2006). Perceptions and uptake of open source in Swedish organisations In: Damiani, E. Fitzgerald B. Scacchi,W. Scotto M. Succi G. (Eds.) Open Source Systems, IFIP International Federation for Information Processing,Volume 203, Springer, Boston. Pp. I55-I53.

LUOMA T. Paasi J.Valkokari, K. (2010). Intellectual property in inter-organizational relationships - Findings from an interview study. International Journal of Innovation Management, I4(3), 399-4I4.

McGOWAN, D. (2005) Legal aspects of free and open source software, In: Feller J. Fitzgerald B., Hissam S., Lakhani K. (Eds.), Perspectives on Free and Open Source Software, MIT Press, London. pp. 2I I-226.

MÄKI-AISALA, P., Matinlassi M. (2006). Quality Assurance of Open Source Components: Integrator Point of View. Proceedings of the 30th Annual International Computer Software and Applications Conference, Second International Workshop on Testing and Quality Assurance for Component-Based Systems, Chicago, September 17-21,2006, 189 $-192$. 
NYMAN, L. Mikkonen, T. (20I I). To Fork or Not to Fork: Fork Motivations in SourceForge Projects. International Journal of Open Source Software and Processes, 3(3), I-9.

OKSANEN, V. (2006). State of Art on Legal research on FLOSS. In: Helender N. Martin-Vanhanen H. (Eds.), Multidisciplinary Views to Open Source Software Business. BRC Research Report \#33. Tampere University of Technology and the University of Tampere, Tampere. Pp. 10-19.

PAASI, J. Luoma T. Valkokari, K. (2010). Knolwedge and Intellectual property management in customer supplyer relationships. International Journal of Innovation Management , 14(4), 629-654.

SANCHEZ,A. Lago,A. Ferràs X. Ribera J. (20II). Innovation Management Practices, Strategic Adaptation, and Business Results: Evidence from the Electronics Industry. Journal of Technology Management and Innovation , 2(6), I4-39.

SAVITSKAYA J., Salmi P,Torkkeli M. (20I0). Barriers to Open Innovation: Case China. Journal of Technology Management and Innovation, 5(4), I0-2I.

SPILLER, D., Wichmann, T. (2002). Floss Final Report - Part 3: Basics of Open Source Software Markets and Business Models. University of Maastricht, Netherlands.

STAM, W. (2009). When does community participation enhance the performance of open source software companies? Research Policy, 38(8), I288-I 299.

TUOMI, I. (2002). Networks of Innovation, Oxford University Press, New York.

VALKOKARI, K. Paasi J. Luoma T. Ling, N. (2009). Beyond open innovation: The concept of networked innovation. In: Huizing, K. Conns, S. Torkkeli M. Bitran, I. (Eds) Stimulating Recovery - The Role of Innovation Managemen, International Society for Professional Innovation Management (ISPIM), New York.

WEST, J. (2007). Value Capture and Value Networks in Open Source Vendor Strategies. 40th Annual Hawaii International Conference on System Sciences (HICSS), January 2007.

WEST, J. Gallagher, S. (2006a) Patterns of Open innovation in open source software development. In: Chesbrough, $\mathrm{H}$. Vanhaverbeke W.West J. (Eds.), Open innovation:researching a new paradigm, Oxford University Press, Oxford.

West, J. Gallagher S. (2006b). Challenges of Open innovation: the paradox of firm investment in open source software. R\&D Management, 36(2), 316-33I .
YE, Y. Kishida, K. (2003). Toward an understanding of the motivation of open source software developers. The proceedings of the 25th International Conference on Software Engineering (ICSE'03), 3-I0 May 2003, 4I 9- 429. 